\title{
Excitatory Glycine Responses of CNS Myelin Mediated by NR1/NR3 “NMDA” Receptor Subunits
}

\author{
Juan C. Piña-Crespo, ${ }^{1,2 *}$ Maria Talantova, ${ }^{2 *}$ Ileana Micu, ${ }^{5 *}$ Bradley States, ${ }^{2}$ H.-S. Vincent Chen, ${ }^{2,4}$ Shichun Tu, ${ }^{2}$ \\ Nobuki Nakanishi, ${ }^{2}$ Gary Tong, ${ }^{2,3}$ Dongxian Zhang, ${ }^{2}$ Stephen F. Heinemann, ${ }^{1,3}$ Gerald W. Zamponi, ${ }^{6}$ Peter K. Stys, ${ }^{5}$ \\ and Stuart A. Lipton ${ }^{2,3}$ \\ ${ }^{1}$ Molecular Neurobiology Laboratory, Salk Institute, and ${ }^{2}$ Center for Neuroscience, Aging, and Stem Cell Research, Sanford-Burnham Medical Research \\ Institute, La Jolla, California 92037, Departments of ${ }^{3}$ Neurosciences and ${ }^{4}$ Cardiology, University of California, San Diego, La Jolla, California 92093 , and \\ Departments of ${ }^{5}$ Clinical Neurosciences and ${ }^{6}$ Physiology and Pharmacology, Hotchkiss Brain Institute, University of Calgary, Calgary, Alberta T2N 4N1, \\ Canada
}

NMDA receptors are typically excited by a combination of glutamate and glycine. Here we describe excitatory responses in CNS myelin that are gated by a glycine agonist alone and mediated by NR1/NR3 "NMDA" receptor subunits. Response properties include activation by D-serine, inhibition by the glycine-site antagonist CNQX, and insensitivity to the glutamate-site antagonist D-APV. D-Serine responses were abrogated in NR3A-deficient mice. Our results suggest the presence of functional NR1/NR3 receptors in CNS myelin.

\section{Introduction}

While the properties of recombinant NR3-containing NMDA receptors (NMDARs) have been studied in various recombinant expression systems (Ciabarra et al., 1995; Sucher et al., 1995; Nishi et al., 2001; Chatterton et al., 2002; Piña-Crespo and Heinemann, 2004; Awobuluyi et al., 2007; Smothers and Woodward, 2007; Talantova et al., 2007), detailed information regarding the functional and pharmacological properties of native NR3containing NMDARs in the mammalian CNS is still lacking. One problem in assessing such activity is that NR3-containing receptors rapidly desensitize in response to glycine (Chatterton et al., 2002; Awobuluyi et al., 2007), and most brain slice preparations manifest high levels of glycine and other amino acids, in part due to tissue injury during slice production or electrophysiological recording. In the present study, to minimize damage to the preparation and therefore preserve normal architecture and function, we used a less invasive, high-resolution $\mathrm{Ca}^{2+}$ imaging technique on intact ex vivo optic nerves (Micu et al., 2006). Our results demonstrate the existence of native NR3containing NMDARs that respond to glycine agonists alone in

\footnotetext{
Received March 26, 2010; revised June 29, 2010; accepted July 7, 2010.

This work was supported in part by National Institutes of Health Grants R01 NSO28709 (S.F.H.) and R01 EY05477, R01 EY09024, and P01 HD29587 (S.A.L.), and by the Canadian Institutes for Health Research, the Alberta Heritage Foundation for Medical Research, and Canada Research Chairs (P.K.S. and G.W.Z). J.C.P.-C. was a Pew Fellow supported by the Pew Charitable Trusts. We thank Dr. Yasunori Hayashi (Picower Center, Massachusetts Institute of Technology) for generously providing cDNA for the mouse NR3B receptor subunit to compare with our own and Dr. Jane M. Sullivan (Department of Physiology and Biophysics, University of Washington) for kindly providing the NR1-GFP plasmid. We also thank Johnson Wong for his valuable help with statistical analysis and Drs. Q. Jiang and J. McRory for assistance with the immunoprecipitation experiments.

*J.C.P.-C., M.T., and I.M. contributed equally to this work.

Correspondence should be addressed to either Stuart A. Lipton or Peter K. Stys at the above addresses. E-mail: slipton@sanfordburnham.org or pstys@ucalgary.ca.

DOI:10.1523/JNEUROSCI.1593-10.2010

Copyright $\odot 2010$ the authors $\quad 0270-6474 / 10 / 3011501-05 \$ 15.00 / 0$
}

optic nerve myelin, while the parent oligodendrocyte somas are unresponsive.

\section{Materials and Methods}

Dye loading and $\mathrm{Ca}^{2+}$ imaging of myelin and oligodendrocytes of live optic nerve. Experiments were performed in accordance with institutional guidelines for the care and use of experimental animals. Adult mice $(20-25 \mathrm{~g})$ or Long-Evans rats (200-225 g) were deeply anesthetized and optic nerves dissected on ice in $0.5 \mathrm{mM} \mathrm{Ca}^{2+}$-CSF buffer containing the following (in mM): $\mathrm{NaCl} 126, \mathrm{NaHCO}_{3} 26, \mathrm{KCl} 3, \mathrm{NaH}_{2} \mathrm{PO}_{4} 1.25, \mathrm{MgSO}_{4}$ 2, $\mathrm{CaCl}_{2}$ 0.5, D-glucose 10; bubbled with $95 \% \mathrm{O}_{2} / 5 \% \mathrm{CO}_{2}$, pH 7.4. Optic nerves were then incubated at $22^{\circ} \mathrm{C}$ in the same buffer containing the $\mathrm{Ca}^{2+}$ indicator X-rhod-1 acetoxymethyl ester $(20 \mu \mathrm{M})$, together with DiOC6(3) (500 nM) to label myelin for $1 \mathrm{~h}$, and then transferred to aCSF solution at $35^{\circ} \mathrm{C}$ for $30 \mathrm{~min}$ to allow de-esterification and washout of excess dye. Imaging was performed at $36^{\circ} \mathrm{C}$ in aCSF solution using a water-immersion objective $(60 \times 1.0 \mathrm{NA}$, Fluor, Nikon) on a Nikon D-Eclipse C1 microscope custom-modified for two-photon microscopy (Ridsdale et al., 2004). Samples were excited with $\sim 50$ fs pulses, $80 \mathrm{MHz}$ repetition rate, at a wavelength of $925 \mathrm{~nm}$ generated by a Ti:sapphire laser (Tsunami; Spectra-Physics Lasers). Emitted fluorescence was filtered appropriately and detected by photomultiplier tubes in two channels. Image data were imported into ImageTrak (written by P.K.S.; http://www. ucalgary.ca/styslab/imagetrak) for visualization and analysis on a Macintosh OS X computer as previously described (Micu et al., 2007); also, as we have previously reported, $\mathrm{Ca}^{2+}$ responses in this preparation take several minutes to reach steady state, probably because of slow penetration of drugs by diffusion into tightly wrapped myelin (Micu et al., 2006). Myelin regions (typically $4 \mu \mathrm{m}$ long by $<0.5 \mu \mathrm{m}$ thick) were randomly selected for analysis over time, and typically 3-4 experiments were replicated for each treatment group. Therefore, in each case " $n$ " represents total myelin regions of interest from several experiments combined for statistical analysis.

Immunoblots and immunoprecipitation. Immunoblots and immunoprecipitation techniques were used to detect the NMDA receptors in the myelin of the rat optic nerve. The myelin sheath was isolated on a sucrose gradient using the methods of Norton and Poduslo (1973). First, optic nerves were homogenized in $0.32 \mathrm{M}$ sucrose and centrifuged in $0.83 \mathrm{M}$ 
sucrose at 75,000 $\times \mathrm{g}$ for $30 \mathrm{~min}$. The collected interphase fraction was washed, centrifuged at $75,000 \times g$ for $10 \mathrm{~min}$, and hypotonic shocked twice at low-speed centrifugation $(12,000 \times g)$ for $10 \mathrm{~min}$, to obtain myelin. Purity of the myelin was assessed by immunoblotting for standard markers such as myelin basic protein, and exclusion of markers such as the endoplasmic reticulum integral membrane calnexin, a marker for cytoplasmic organelles. Myelin fractions were incubated on ice for $1 \mathrm{~h}$ in a buffer (300 mM NaCl, $50 \mathrm{~mm}$ Tris, $\mathrm{pH} 7.5$, and $0.1 \%$ Triton X-100), and then centrifuged for $15 \mathrm{~min}\left(4^{\circ} \mathrm{C}\right)$ at $15,000 \times g$. The supernatant was collected and mixed with pan-NR1 monoclonal antibody (1:100 dilution; Calbiochem) and Protein G-Sepharose and incubated overnight at $4^{\circ} \mathrm{C}$. The samples were then incubated at room temperature for $1 \mathrm{~h}$ and washed with a buffer containing (0.2\% NP-40, $10 \mathrm{~mm}$ Tris, $\mathrm{pH} 7.5,0.15$ $\mathrm{M} \mathrm{NaCl}$, and 2 mM EDTA), one time with the same buffer in which $\mathrm{NaCl}$ concentration was increased to $0.5 \mathrm{M} \mathrm{NaCl}$, and one time with $10 \mathrm{~mm}$ Tris, $\mathrm{pH}$ 7.5. The mixture was centrifuged and resuspended in $25 \mu \mathrm{l}$ of 3 M urea/10 mM Tris, pH 7.5. An additional $25 \mu \mathrm{l}$ of $2 \times$ sample buffer was added to each aliquot, which was then boiled for $5 \mathrm{~min}$ and loaded onto a $6 \%$ acrylamide SDS-PAGE gel. The samples were transferred to PVDF membrane and Western analysis was performed using a NR1 polyclonal (1:500; pan-NR1, Millipore \#07-362; Millipore Bioscience Research Reagents \#AB1516), NR2 polyclonal (1:1000; Affinity BioReagents \#OPA104020), which recognizes NR2A-2C and possibly NR2D subunits, or NR3 monoclonal antibody (Millipore Bioscience Research Reagents \#MAB5388), which recognizes both NR3A and NR3B subunits, and whose specificity for these receptors has been previously established (Das et al., 1998). Immunoreactive bands were detected using enhanced chemiluminescence. Appropriate negative controls were performed by omitting the primary precipitating antibody and by removing or probing only with secondary antibody.

Electrophysiological recordings. Whole-cell recordings were performed 24-72 h after transfection at room temperature using a patch-clamp amplifier (Axopatch 200B or Multiclamp 700A, Molecular Devices). HEK293 cells were constantly superfused at a rate of $2 \mathrm{ml} / \mathrm{min}$ with a HEPES-buffered external solution composed of the following (in $\mathrm{mm}$ ): $\mathrm{NaCl} 146 ; \mathrm{KCl}_{2} .5, \mathrm{CaCl}_{2} 2, \mathrm{MgCl}_{2}$ 1, D-glucose 20, HEPES 10, adjusted to pH 7.4 with $\mathrm{NaOH}, 310$ mOsm. We also used a nominally magnesiumfree extracellular solution composed of the following (in mM): $\mathrm{NaCl} 150$, $\mathrm{KCl} 3$, HEPES 10, D-glucose $10, \mathrm{CaCl}_{2} 1.8$, adjusted to $\mathrm{pH} 7.4$ with $\mathrm{NaOH}$. Patch pipettes were pulled from borosilicate glass capillaries (GC150F-10, Harvard Apparatus) using a Flaming/Brown micropipette puller (P80/PC, Sutter Instruments). Patch pipettes had open tip resistances of 3-6 $\mathrm{M} \Omega$ after fire polishing in a microforge (P83, Narishige) and filled with an internal solution composed of (in mM): $\mathrm{CsCl} 140, \mathrm{NaCl}$ 4, $\mathrm{CaCl}_{2}$ 0.5, EGTA 5, HEPES 10, Na-GTP 0.5, and Mg-ATP 2, adjusted to $\mathrm{pH} 7.33$ with $\mathrm{CsOH}, 315 \mathrm{mOsm}$. In some experiments, we used a Cs-gluconate-based intracellular solution composed of the following (in mu): Cs-gluconate 117, $\mathrm{NaCl}$ 9, HEPES 10, EGTA 10, and $\mathrm{MgCl}_{2} 2$, adjusted to $\mathrm{pH} 7.2$ with $\mathrm{NaOH}$. For single-channel activity of NR1/ NR3A/NR3B with or without NR2A subunits, we recorded from excised patches in the outside-out configuration using the patch-clamp technique. Patch pipettes had a final pipette tip resistance of 7-14 $\mathrm{M} \Omega$ at -60 $\mathrm{mV}$. For single-channel recordings, patch pipettes were filled with an internal solution composed of the following (in mM): Na-gluconate 140, $\mathrm{NaCl}$ 10, HEPES 10, EGTA 10, adjusted to pH 7.2 with $\mathrm{NaOH}$. Membrane patches obtained in the presence of external $\mathrm{CaCl}_{2}$ were then transferred to a $\mathrm{Ca}^{2+}$-free bath solution (in $\mathrm{mM}$ ): $\mathrm{NaCl} 170, \mathrm{KCl} 3$, HEPES 5, EGTA 50-100 $\mu \mathrm{m}$ without added $\mathrm{CaCl}_{2}$, adjusted to $\mathrm{pH} 7.4$ with $\mathrm{NaOH}$. All solutions were prepared from high-purity reagents (Golden Label, Sigma-Fluka) in HPLC grade water (Sigma).

Agonist application. Glycine and other agonists/antagonists were administered either by pressure application or by a fast valve-controlled perfusion system (Lee Company). All agonists and antagonists were purchased from Tocris Bioscience unless otherwise noted. For pressure application, brief pulses (100-300 ms) of agonist solution (e.g., glycine, 1 $\mathrm{mm}$ ) were applied onto the cells using micropipettes connected to a Picospritzer II (General Valve Corporation).

Data acquisition and analysis. Electrical signals were filtered, digitized, and stored on a Dell computer using PClamp v.8-10 software (Molecu- lar Devices). Digitized single-channel traces were analyzed using the TAC software program (TAC X4.1, Bruxton). Display and analysis of singlechannel data distributions were done using a statistical software package (Origin 7, OriginLab).

Statistical analysis. ANOVA with Tukey's HSD test was used for multiple comparisons. Results are expressed as mean \pm SEM. Gaussian functions were fitted to single-channel current amplitude distributions using a nonlinear regression method based on the Levenberg-Marquardt algorithm in Origin 7 (OriginLab).

HEK293 cell culture and transfection. HEK293 cells (CRL-1573, ATCC) were cultured in $25 \mathrm{~cm}^{2}$ tissue culture flasks (Corning) containing 8-10 $\mathrm{ml}$ of medium composed of DMEM (Cellgro), 10\% fetal bovine serum (Invitrogen), $1 \%$ glutamine (Invitrogen), and 1\% penicillin-streptomycin (Invitrogen). Cells were incubated at $37^{\circ} \mathrm{C}$ and $8 \% \mathrm{CO}_{2}$, plated $24 \mathrm{~h}$ before transfection onto $12 \mathrm{~mm}$ glass coverslips coated with poly-Llysine, and split every $3 \mathrm{~d}$ for no more than 20 passages. Cell monolayers at $\sim 70 \%$ confluency were nonenzymatically dissociated using $0.02 \%$ EDTA in PBS (Versene, Invitrogen) and then dissociated mechanically by gentle trituration until a single-cell suspension was obtained. For seeding, $125-250 \mu \mathrm{l}$ of the cell suspension were added to a new flask containing $8-10 \mathrm{ml}$ of cell culture medium. In all of the experiments shown here on HEK293 cells, transfections were performed $24-72 \mathrm{~h}$ before recording with NR1-1a (or NR1-GFP), NR3A (or NR3A-YFP), $\mathrm{NR} 3 \mathrm{~B}$, and in some cases NR2A subunits following standard protocols using either calcium phosphate (CalPhos, Clontech), FuGENE 6 (Roche Applied Science), or Effectene (QIAGEN). Plasmid cDNAs were mixed at a ratio of 1:2:2(:2) and added to HEK293 cells. The YFP- and GFPlabeled subunits produced similar results to the unlabeled subunits.

GenBank accession numbers. The following clones were used: NR1 (U08261), NR2A (D13211), NR3A (L34938, U29873), and NR3B (AF440691, AF396649).

\section{Results}

\section{NR1/NR3 receptor complexes are present in myelin and are} sensitive to D-serine

Probing the isolated myelin fraction from adult rat optic nerve by immunoblot with NMDAR subunit-specific antibodies (Micu et al., 2006), we found NR1 subunits associated with NR2 or NR3 subunits; NR3 subunits, however, were exclusively associated with NR1 and not NR2 subunits (Fig. $1 A$ ). The specificity of NMDAR subunit localization to myelin, rather than axolemma, which may contaminate myelin extractions, is further supported by previous observations indicating no detectable functional NMDARs on axon membranes of optic nerve [see Micu et al. (2006), their supplemental Fig. 3]. Since the current findings suggested the presence of NMDARs containing both NR1 and NR3 subunits in mature optic nerve myelin, we used D-serine, a glycine-binding site agonist of classical NMDARs that is known to activate NR1/NR3 receptors (Chatterton et al., 2002; Awobuluyi et al., 2007; Smothers and Woodward, 2007). We found that D-serine elicited $\mathrm{Ca}^{2+}$ responses from myelin (Fig. $1 \mathrm{~B}$; supplemental Fig. 4, available at www.jneurosci.org as supplemental material). Application of D-serine produced a significant increase in fluorescence of the $\mathrm{Ca}^{2+}$-sensing dye X-rhod-1 in optic nerve myelin from wild-type (WT) mice $[15 \pm 1.2 \%$ increase, mean \pm SEM, $n=39$ regions of interest (ROIs) in 4 experiments; $p \leq$ 0.001] (Fig. 1B). D-Serine also evoked whole-cell currents from recombinant NR1/NR3 receptors expressed in mammalian cells, which were used here to verify the pharmacological specificity of our reagents (Fig. $2 A$ ).

\section{NR1/NR3 receptor complexes are CNQX sensitive and APV insensitive}

Furthermore, CNQX, a glycine-binding site antagonist of NMDARs (Lester et al., 1989) also known to inhibit NR1/NR3 receptors (Madry et al., 2007) (Fig. 2B), completely blocked the 
A
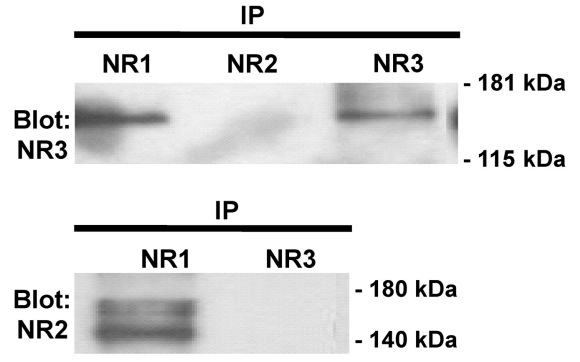

C
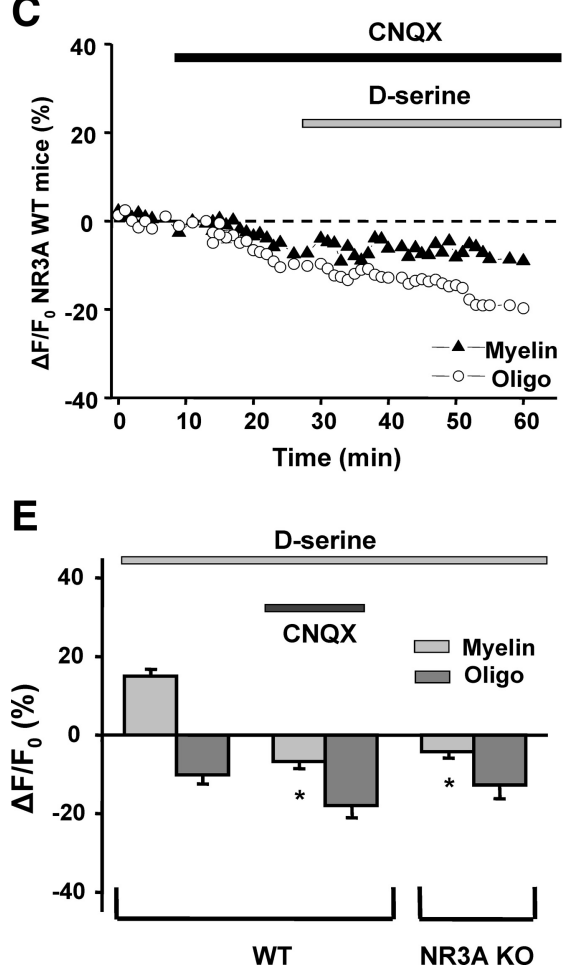

B

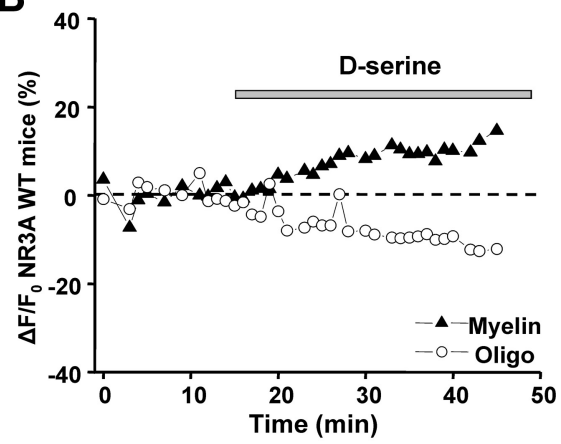

D

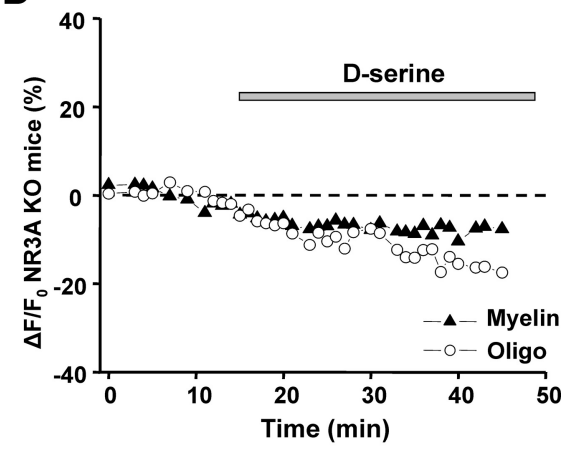

$\mathbf{F}$

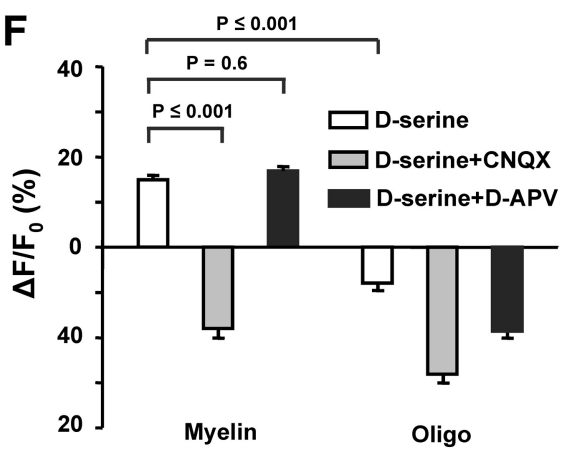

Figure 1. Presence and physiological response of NR1/NR3 receptors in optic nerve myelin. $\boldsymbol{A}$, Coimmunoprecipitation from the myelin fraction using antibodies against NMDAR subunits. Antibodies used for the precipitation are indicated above the lanes. The membrane was probed with an anti-NR3 antibody (upper blot) and a pan-NR2 antibody (bottom blot), yielding evidence for NR1/NR3 but not NR2/NR3-containing complexes. Molecular weight markers are indicated at right. $\boldsymbol{B}$, Addition of $500 \mu \mathrm{m}$ D-serine induced a rise in $\mathrm{Ca}^{2+}$ in myelin from WT mice within minutes of application, an effect not observed in oligodendrocyte cell bodies. C, Rise in myelinic $\mathrm{Ca}^{2+}$ in response to D-serine was completely abrogated by $40 \mu \mathrm{M}$ CNQX. D, In NR3A KO mice, D-serine failed to induce a rise in myelinic $\mathrm{Ca}^{2+} . \boldsymbol{E}$, Bar graph summarizing mean intensity change in fluorescence of the $\mathrm{Ca}^{2+}$-sensitive dye Xrhod-1 in myelin and oligodendrocyte somal cytoplasm of WT and NR3A K0 mice after application of D-serine $\left({ }^{* *} p \leq 0.001\right.$ vs WT myelin exposed to D-serine). $\boldsymbol{F}$, In rat, as in mouse, D-serine evoked significant increases in myelinic but not oligodendrocyte cell body $\mathrm{Ca}^{2+}$. The myelinic $\mathrm{Ca}^{2+}$ response was completely blocked by CNQX but unaffected by D-APV (200 $\left.\mu \mathrm{M}\right)$.

D-serine-induced rise in myelinic $\mathrm{Ca}^{2+}$ in WT myelin $(-7 \pm$ $1.2 \%, n=65 \mathrm{ROI}$ in 3 experiments; $p \leq 0.001$ ) (Fig. $1 C$ ). Importantly, D-serine failed to cause an increase in $\mathrm{Ca}^{2+}$ in optic nerve myelin derived from NR3A knock-out $(\mathrm{KO})$ mice $(-4 \pm 1.1 \%$, $n=69$ ROI in 4 experiments, $p \leq 0.001$ ) (Fig. $1 D, E$ ). In contrast to its effects on the myelin compartment, D-serine produced no significant effect on WT $(-10 \pm 1.9 \%, n=11$ ROI in 3 experiments) or KO oligodendrocyte somas (Fig. $1 B, D, E$ ). $\mathrm{Ca}^{2+}$ imaging in optic nerves from rat yielded similar results to those of WT mice; D-serine induced a significant rise in $\mathrm{Ca}^{2+}$ in myelin $(15 \pm$ $0.6 \%, n=123$ in 6 experiments by paired $t$ test, $p \leq 0.001$ ) (Fig. $1 F$ ) but not in oligodendrocyte somas $(-8 \pm 1.9 \%, n=29)$ (Fig. $1 F)$, and the myelinic $\mathrm{Ca}^{2+}$ increase was completely blocked by
CNQX $(-18 \pm 1.4 \%, n=60, p \leq 0.001$, in 3 experiments) (Fig. $1 F$ ). In contrast to CNQX, D-APV, a glutamate-site antagonist at NR2-containing NMDARs (Paoletti and Neyton, 2007), had no significant effect on D-serine-induced $\mathrm{Ca}^{2+}$ increases in optic nerve myelin $(17 \pm 0.9 \%$, $n=61, p=0.6$, in 4 experiments) (Fig. $1 F$ ) or on electrophysiological responses of recombinant NR1/NR3 receptors (Fig. 2C,D). In contrast, D-APV blocked virtually completely the responses of NR1/NR2/NR3 triheteromeric recombinant receptors (Fig. $2 E$ ) as well as NR1/NR2 di-heteromeric receptors (Sasaki et al., 2002).

\section{Discussion}

In the present study, we observed D-serineevoked responses from CNS myelin with pharmacological properties consistent with activation of NR1/NR3 receptors. To characterize these responses more thoroughly in a mammalian expression system, we performed a detailed functional analysis of recombinant NR3A and NR3B subunits coexpressed with NR1 subunits in HEK293 cells (supplemental Fig. 1, available at www.jneurosci.org as supplemental material). Our studies revealed the excitatory nature of these glycine-evoked currents, characterized by rapid albeit incomplete desensitization (supplemental Fig. 2, available at www.jneurosci.org as supplemental material) and reduced sensitivity to $\mathrm{Mg}^{2+}$ blockade (Fig. 2A). The currents were virtually insensitive to $\mathrm{Mg}^{2+}$ at membrane potentials above $-60 \mathrm{mV}$ but somewhat blocked by $\mathrm{Mg}^{2+}$ at more negative potentials (supplemental Fig. $3 B$, available at www.jneurosci.org as supplemental material). Analysis of the pharmacological properties of NR1/NR3A/NR3B receptors demonstrated activation by glycine alone in the absence of glutamate (or NMDA) and insensitivity to the NR2 glutamate binding-site antagonist D-APV (PiñaCrespo and Heinemann, 2004; Smothers and Woodward, 2007; Talantova et al., 2007). The NR1 glycine binding-site antagonists DCKA and MDL exhibited dual effects on NR1/NR3A/NR3B receptors, inhibiting peak currents but potentiating steady-state currents (supplemental Fig. 3C, available at www.jneurosci.org as supplemental material). We and our colleagues had observed similar phenomena in oocytes and suggested that these divergent effects might occur because of the differential affinities of MDL and DCKA for the glycine binding-sites on NR1 versus NR3 subunits (Awobuluyi et al., 2007; Madry et al., 2007).

These studies of recombinant channels expressed in mammalian cells made us realize that determining whether functional NR1/NR3 receptors exist in vivo on native cells required overcoming several technical hurdles. For example, desensitization may occur due to endogenous levels of glycine in the CNS, ex- 
A

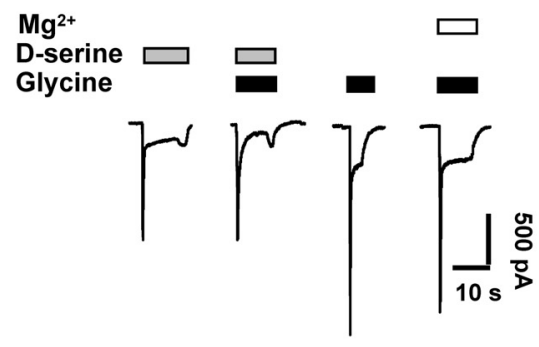

B

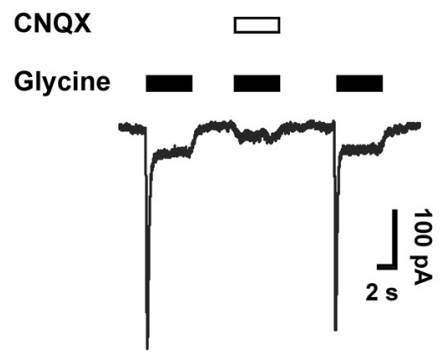

C

D
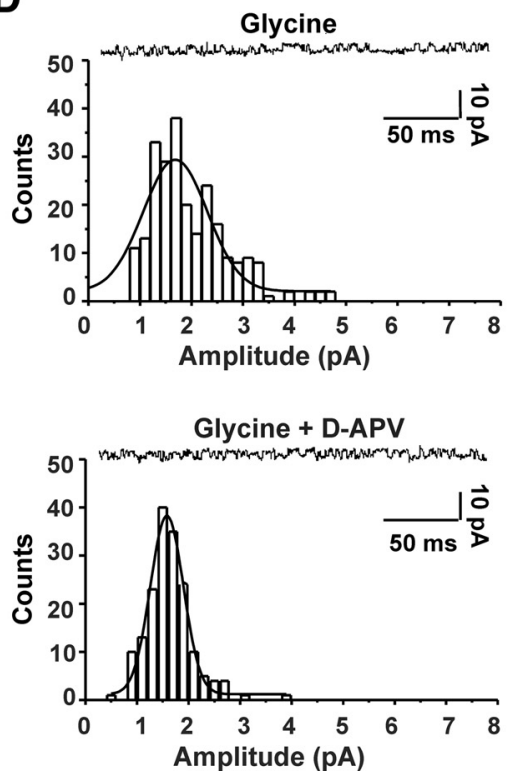

E
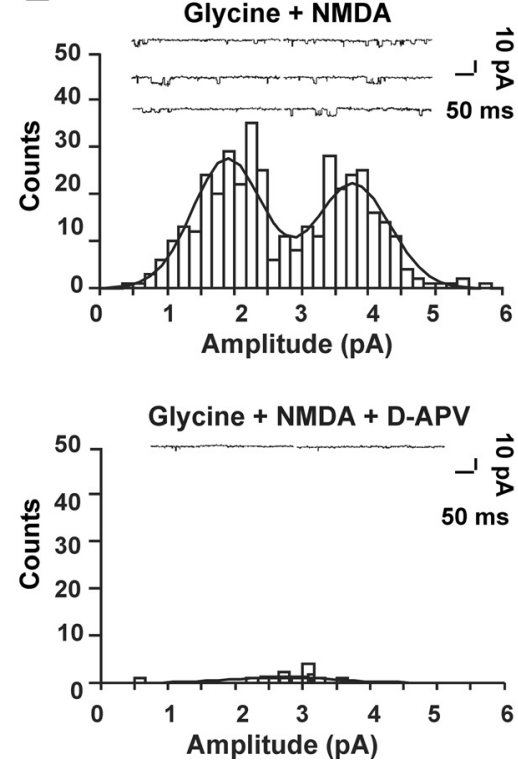
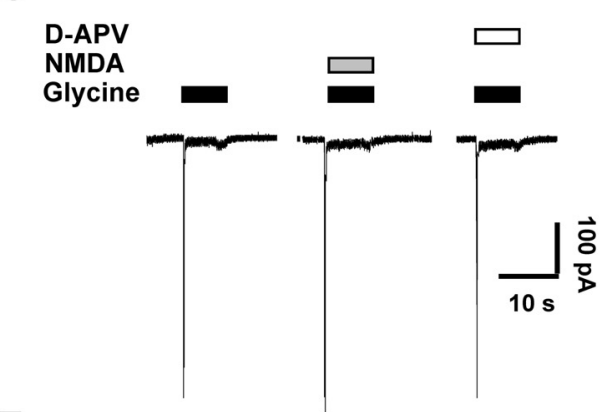

$\mathbf{F}$
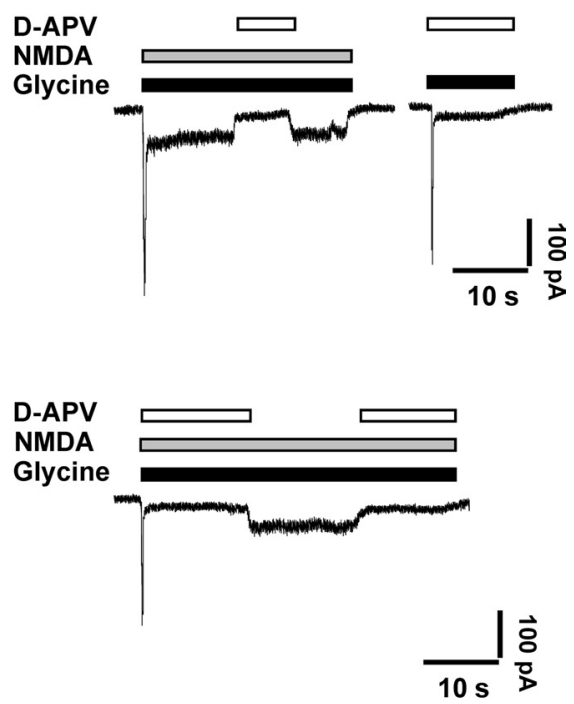

Figure 2. Patch-clamp recordings to show pharmacological properties of recombinant NR1/NR3 receptors expressed in HEK293 cells. $A$, D-Serine (200 $\mu \mathrm{M})$ evoked currents in cells expressing recombinant NR1/NR3 receptors. Currents were observed even in the presence of $1 \mathrm{~mm}$ external $\mathrm{Mg}^{2+}$ (complete $/ / V$ relationship shown in supplemental Fig. 3B, available at www.jneurosci.org as supplemental material). $\boldsymbol{B}, \mathrm{CNQX}(20 \mu \mathrm{m})$ inhibited the peak amplitude of glycine-evoked currents from NR1/NR3 receptors by $\sim 93 \%$, with less prominent block ( $\sim 60 \%)$ of the steady-state response $(n=5)$. C, D-APV failed to inhibit glycine-evoked currents even at high micromolar concentrations ( $200 \mu \mathrm{M})$. D, Glycine (200 $\mu \mathrm{M})$ evoked single-channel activity with a unitary conductance of $28.3 \pm 1.3 \mathrm{pS}$ (mean \pm SEM; coapplication of $100 \mu \mathrm{M} \mathrm{D}$-APV did not affect single-channel activity or conductance $(26.7 \pm 3.3 \mathrm{pS} ; n=413$ events from 7 patches). $\boldsymbol{E}$, In NR1-, NR2-, and NR3-transfected HEK cells, $200 \mu \mathrm{m}$ glycine plus $100 \mu \mathrm{m}$ NMDA evoked single-channel activity with single-channel conductances of $32.0 \pm 0.7$ and $61.7 \pm 0.7 \mathrm{pS}$ (mean \pm SEM, $n=401$ ). Coapplication of $100 \mu \mathrm{m}$ D-APV blocked virtually all single-channel activity ( $n=4$ patches). Gaussian functions were fitted to single-channel current amplitude distributions using a nonlinear regression method based on the Levenberg-Marquardt algorithm. Holding potential, $-60 \mathrm{mV}$. F, NR1-, NR2-, and NR3-transfected HEK cells generated different populations of recombinant NMDAR subtypes. In whole-cell recordings, $100 \mu \mathrm{M}$ D-APV blocked virtually all of the steady-state current evoked by $100 \mu \mathrm{M}$ NMDA plus $200 \mu \mathrm{m}$ glycine, consistent with the presence of NR2-containing receptors (either NR1/NR2 di-heteromeric receptors or NR1/NR2/NR3 tri-heteromeric receptors). In contrast, up to $200 \mu \mathrm{m} \mathrm{D}$-APV only partially inhibited the peak current evoked by NMDA plus glycine, suggesting the presence of an additional population of NMDARs lacking NR2 subunits; since this second population underlying the initial peak current was activated by glycine alone in the presence of D-APV (top right panel), it most likely consisted of NR1/NR3 subunits. Holding potential, $-60 \mathrm{mV}$ in each panel.

pression of NR3A and NR3B may need to overlap with NR1, and relatively high concentrations of glycine may be required for receptor activation.

The results presented here using $\mathrm{Ca}^{2+}$ imaging of myelin in rodent optic nerve strongly suggest that functional NR1/NR3 receptors are expressed in this compartment. Although the unitary conductance of these receptors may be small, as demonstrated with recombinant channels (Chatterton et al., 2002), the tiny cytoplasmic volume of the myelin sheath may result in substantial and sustained increases in $\left[\mathrm{Ca}^{2+}\right]$ in response to agonist application. The relatively low $\mathrm{Ca}^{2+}$ permeability of NR1/NR3 receptors, coupled with their relative resistance to $\mathrm{Mg}^{2+}$ blockade at negative membrane potentials (Nishi et al., 2001; Chatterton et al., 2002; Awobuluyi et al., 2007; Smothers and Woodward, 2007) (Fig. $2 A$; supplemental Fig. 3B, available at www.jneurosci.org as supplemental material), renders NR3-containing receptors ideally suited as mediators of physiological $\mathrm{Ca}^{2+}$ fluctuations in the nanometer-scale myelinic cytoplasmic compartment, where only small amounts of ion are expected to change local concentrations quite substantially. This situation is quite distinct from synaptic endings, where volumes are larger and therefore a mechanism for depolarization to relieve $\mathrm{Mg}^{2+}$ blockade is required to mediate the Hebbian effect of conventional NMDARs. Indeed, the lower $\mathrm{Ca}^{2+}$ permeability of these novel glycine-activated NR1/NR3 receptors may be essential to avoid $\mathrm{Ca}^{2+}$ overload of the minute cytosolic compartment within the myelin spiral. An alternate route of $\mathrm{Ca}^{2+}$ accumulation in the myelin sheath, secondary, for example, to membrane depolarization by NR1/NR3 receptors to trigger voltage-dependent $\mathrm{Ca}^{2+}$ channels, is unlikely because direct depolarization of optic nerve with $45 \mathrm{mM} \mathrm{K}^{+}$ did not elicit a rise in $\mathrm{Ca}^{2+}$ (I. Micu and P. K. Stys, unpublished observations). In fact, this finding suggests that neither voltage-gated $\mathrm{Ca}^{2+}$ channels nor reverse $\mathrm{Na}^{+}-\mathrm{Ca}^{2+}$ exchange play a major role in $\mathrm{Ca}^{2+}$ accumulation in myelin processes. Additionally, although there is some evidence for functional AMPA/kainate receptors on 
myelin (Li and Stys, 2000), these would not be expected to respond to D-serine, as observed here. Together, our results are most consistent with $\mathrm{Ca}^{2+}$ entry into mature myelin in response to D-serine exposure via NR1/NR3 receptor-coupled channels, although additional contributions, e.g., from mobilization of intracellular $\mathrm{Ca}^{2+}$, cannot be totally excluded. During pathological conditions, such as ischemia, NMDARs containing NR2 subunits may also play an important role in mediating $\mathrm{Ca}^{2+}$ entry into myelin, given the inhibitory effect of D-APV under these conditions (Káradóttir et al., 2005; Salter and Fern, 2005; Micu et al., 2006).

The differences in pharmacology and function of NMDARs on myelin versus oligodendrocyte somas can be explained by the ability of mammalian cells to generate NMDAR subtypes of disparate subunit composition (Fig. $2 F$ ). For example, D-APVinsensitive NR1/NR3 receptors appear to be restricted to myelin, while D-APV-sensitive NR2-containing receptors manifest a wider distribution (Káradóttir et al., 2005; Salter and Fern, 2005; Micu et al., 2006). The unexpected rise in glycine-site agonistinduced myelinic $\mathrm{Ca}^{2+}$ in the absence of change in the oligodendrocyte soma (Fig. $1 B$; supplemental Fig. 4, available at www. jneurosci.org as supplemental material) may underlie tissue damage to myelin more than cell bodies in the clinical setting of periventricular leukomalacia in preterm infants, where excitation of NMDAR subunits has been reported to play a role (Billiards et al., 2008; Manning et al., 2008); similarly, these responses may possibly contribute to demyelination in the mature CNS in multiple sclerosis, where increases in excitotoxins occur in neuroinflammatory lesions. Thus, the presence of unique NMDA receptor subtypes in myelin may have important implications for our understanding and treatment of disorders of white matter.

\section{References}

Awobuluyi M, Yang J, Ye Y, Chatterton JE, Godzik A, Lipton SA, Zhang D (2007) Subunit-specific roles of glycine-binding domains in activation of NR1/NR3 N-methyl-d-aspartate receptors. Mol Pharmacol 71:112-122.

Billiards SS, Haynes RL, Folkerth RD, Borenstein NS, Trachtenberg FL, Rowitch DH, Ligon KL, Volpe JJ, Kinney HC (2008) Myelin abnormalities without oligodendrocyte loss in periventricular leukomalacia. Brain Pathol 18:153-163.

Chatterton JE, Awobuluyi M, Premkumar LS, Takahashi H, Talantova M, Shin Y, Cui J, Tu S, Sevarino KA, Nakanishi N, Tong G, Lipton SA, Zhang D (2002) Excitatory glycine receptors containing the NR3 family of NMDA receptor subunits. Nature 415:793-798.

Ciabarra AM, Sullivan JM, Gahn LG, Pecht G, Heinemann S, Sevarino KA (1995) Cloning and characterization of chi-1: a developmentally regulated member of a novel class of the ionotropic glutamate receptor family. J Neurosci 15:6498-6508.

Das S, Sasaki YF, Rothe T, Premkumar LS, Takasu M, Crandall JE, Dikkes P, Conner DA, Rayudu PV, Cheung W, Chen HS, Lipton SA, Nakanishi N (1998) Increased NMDA current and spine density in mice lacking the NMDA receptor subunit NR3A. Nature 393:377-381.
Káradóttir R, Cavelier P, Bergersen LH, Attwell D (2005) NMDA receptors are expressed in oligodendrocytes and activated in ischaemia. Nature 438:1162-1166

Lester RA, Quarum ML, Parker JD, Weber E, Jahr CE (1989) Interaction of 6-cyano-7-nitroquinoxaline-2,3-dione with the N-methyl-d-aspartate receptor-associated glycine binding site. Mol Pharmacol 35:565-570.

Li S, Stys PK (2000) Mechanisms of ionotropic glutamate receptormediated excitotoxicity in isolated spinal cord white matter. J Neurosci 20:1190-1198

Madry C, Mesic I, Bartholomäus I, Nicke A, Betz H, Laube B (2007) Principal role of NR3 subunits in NR1/NR3 excitatory glycine receptor function. Biochem Biophys Res Commun 354:102-108.

Manning SM, Talos DM, Zhou C, Selip DB, Park HK, Park CJ, Volpe JJ, Jensen FE (2008) NMDA receptor blockade with memantine attenuates white matter injury in a rat model of periventricular leukomalacia. J Neurosci 28:6670-6678.

Micu I, Jiang Q, Coderre E, Ridsdale A, Zhang L, Woulfe J, Yin X, Trapp BD, McRory JE, Rehak R, Zamponi GW, Wang W, Stys PK (2006) NMDA receptors mediate calcium accumulation in myelin during chemical ischaemia. Nature 439:988-992.

Micu I, Ridsdale A, Zhang L, Woulfe J, McClintock J, Brantner CA, Andrews SB, Stys PK (2007) Real-time measurement of free $\mathrm{Ca}^{2+}$ changes in CNS myelin by two-photon microscopy. Nat Med 13:874-879.

Nishi M, Hinds H, Lu HP, Kawata M, Hayashi Y (2001) Motoneuronspecific expression of NR3B, a novel NMDA-type glutamate receptor subunit that works in a dominant-negative manner. J Neurosci 21:RC185.

Norton WT, Poduslo SE (1973) Myelination in rat brain: method of myelin isolation. J Neurochem 21:749-757.

Paoletti P, Neyton J (2007) NMDA receptor subunits: function and pharmacology. Curr Opin Pharmacol 7:39-47.

Piña-Crespo JC, Heinemann SF (2004) Physiological and pharmacological properties of recombinant NR3-containing receptors expressed in mammalian cells. Soc Neurosci Abstr 30:957.1.

Ridsdale A, Micu I, Stys PK (2004) Conversion of the Nikon C1 confocal laser-scanning head for multiphoton excitation on an upright microscope. Appl Opt 43:1669-1675.

Salter MG, Fern R (2005) NMDA receptors are expressed in developing oligodendrocyte processes and mediate injury. Nature 438:1167-1171.

Sasaki YF, Rothe T, Premkumar LS, Das S, Cui J, Talantova MV, Wong HK, Gong X, Chan SF, Zhang D, Nakanishi N, Sucher NJ, Lipton SA (2002) Characterization and comparison of the NR3A subunit of the NMDA receptor in recombinant systems and primary cortical neurons. J Neurophysiol 87:2052-2063.

Smothers CT, Woodward JJ (2007) Pharmacological characterization of glycine-activated currents in HEK 293 cells expressing N-methyl-daspartate NR1 and NR3 subunits. J Pharmacol Exp Ther 322:739-748.

Sucher NJ, Akbarian S, Chi CL, Leclerc CL, Awobuluyi M, Deitcher DL, Wu MK, Yuan JP, Jones EG, Lipton SA (1995) Developmental and regional expression pattern of a novel NMDA receptor-like subunit (NMDAR-L) in the rodent brain. J Neurosci 15:6509-6520.

Talantova M, Piña-Crespo JC, States B, Chen, VH-S, Tong G, Zhang D, Heinemann SF, Lipton SA (2007) Unique functional properties of NR3containing "NMDA" receptors expressed in mammalian cells. Soc Neurosci Abstr 33:875.27. 